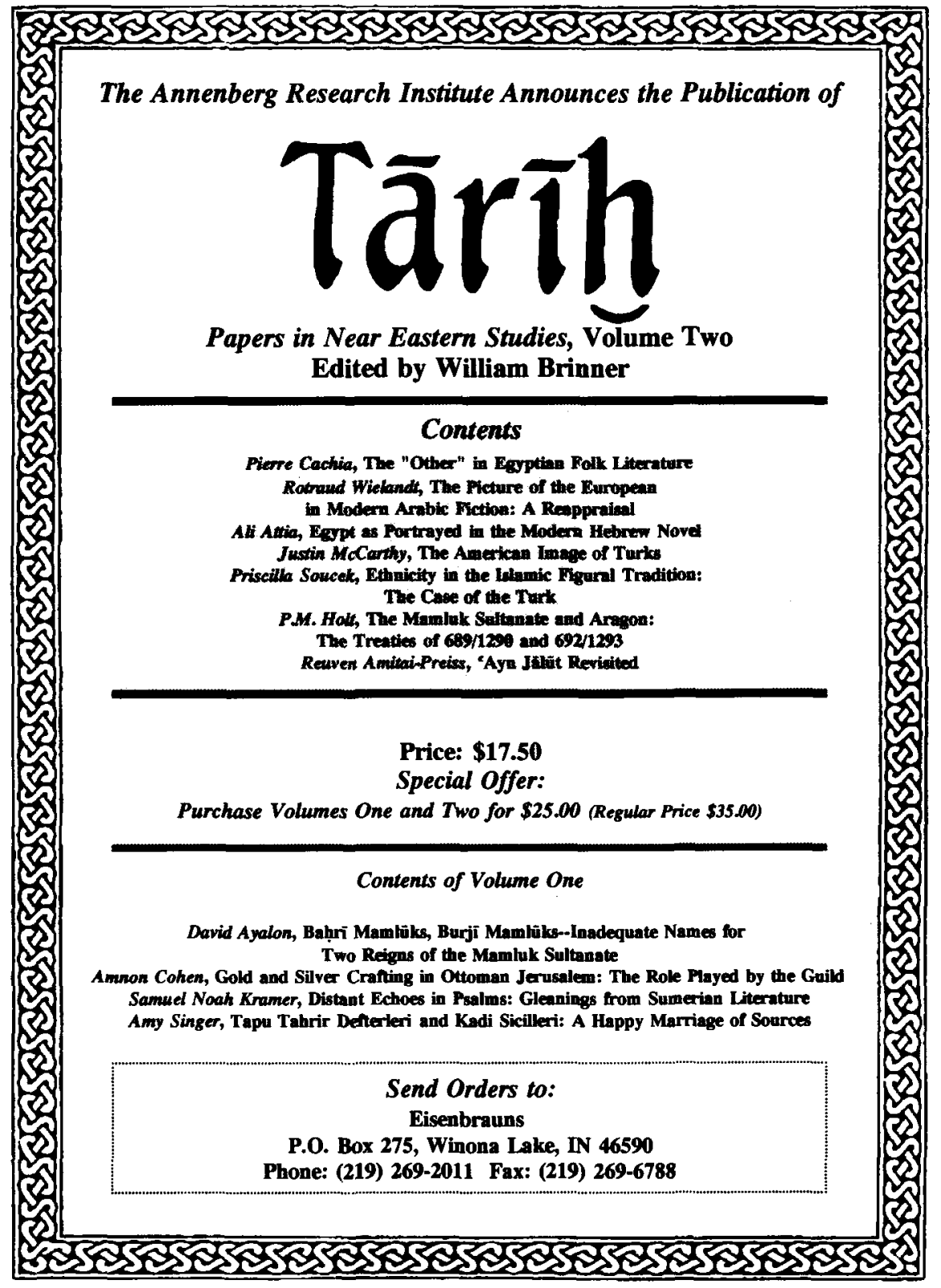




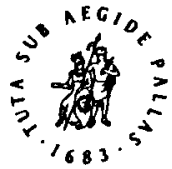

\section{A History of Writing} in Japan

\section{Christopher Seeley}

Deals chronologically with the history of writing in Japan, a subject which spans a period of 2,000 years.

Brill's Japanese Studies Library, 3 1991. (xviii, 243 pp.)

ISBN 9004090819

Cloth Gld. 150.00/US\$ 85.75

\section{Story-Telling}

Techniques in the

\section{Arabian Nights}

\section{David Pinault}

A literary comparison of surviving alternative versions of selected narrative-cycles from the Nights. Studies in Arabic Literature, 15 1992. (xii, 264 pp.) ISBN 9004095306

Cloth with dustjacket

Gld. 115.00/US\$ 65.75

\section{Asia's First Modern Revolution \\ Mongolia Proclaims its \\ Independence in 1911}

U. Onon and D. Pritchatt

1989. (xi, 205 pp.)

ISBN 9004083901

Cloth Gld. 118.00/US\$59.00
Publishers and Booksellers

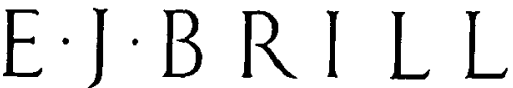

A History of Zoroastrianism

Under Macedonian and Roman

Rule. With F. Grenet. Contribution by R. Beck

Mary Boyce and Frantz Grenet

Traces the history of

Zoroastrianism at times and places where its existence has previously been largely ignored, or treated only episodically.

Handbuch der Orientalistik. 1. Abteilung. Der Nahe und der Mittlere Osten. Band 8.

Religion, 1/2/2/3

1991. (xix, 596 pp.)

ISBN 9004092714

Cloth Gld. 380.00/US\$ 217.25

\section{A History of Law in} Japan until 1868

\section{Carl Steenstrup}

Japan's modern written law is Westem. However, this law operates in a society whose values are pre-Western. In order to understand the function of modern law one has to study older systems of law as well.

Handbuch der Orientalistik. 5. Abteilung. Japan. Band 6. Staat, Staatsdenken, 2/1 1991. (xiii, 202 pp.) ISBN 9004094059 Cloth Gld. 95.00/US\$ 54.50

P.O.B. 9000 - 2300 PA Leiden • The Netherlands / U.S. and Canadian customers - 24 Hudson Street - Kinderhook, NY 12106 - USA. Call toll-free 1-800-962-4406 (US and Canada only). Prices are subject to change without prior notice and are exclusive of handling costs. USS prices are valid for USA and Canada only. 


\section{$\mathrm{O}$

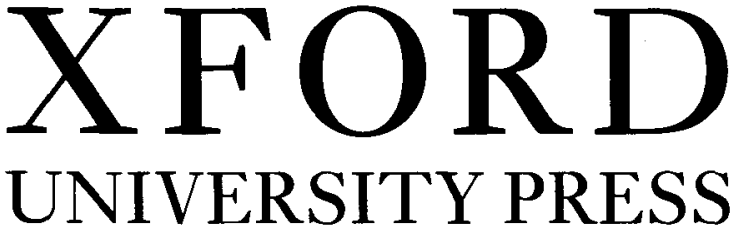

龉

\section{Indirect Rule in India}

Residents and the Residency System 1764-1858

\section{MICHAEL H. FISHER}

Explores the origins, growth, and function of the Residency system on a pan-Indian scale, focusing on the three groups within it: British Residents, Indian rulers, and the Indian staff of the residencies.

0195626761,532 pages, 7 tables,

5 charts, 3 maps, OUP India

f.18.00

\section{Huseyn Shaheed}

\section{Suhrawardy: A Biography}

\section{BEGUM SHAISTA}

\section{SUHRAWARDY IKRAMULLAH}

'a valuable addition to the political literature of Pakistan.' The Nation

A personal biography of one of Pakistan's most colourful and controversial political figures, written by his cousin.

0195774140,204 pages, 12 pp plates, OUP Pakistan

\section{Peasant}

\section{Movements in}

\section{India 1920-1950}

\section{N. DHANAGARE}

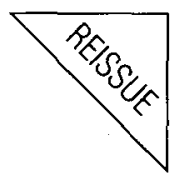

This study has become established as the most important analysis of the role of the peasantry in revolutionary or nearrevolutionary movements in India.

0195629035,268 pages, 10 tables, 6 maps, Oxford India Paperbacks

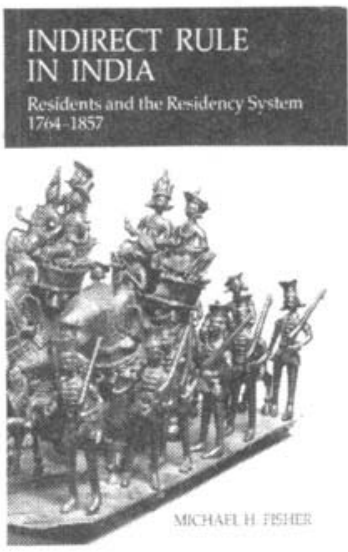

\section{The Unification and Division of India}

\section{B. B. MISRA}

Traces how the subcontinent was unified under British rule, and how with the growth of democracy in the last years of the Raj the divisions inherent in India's plural society led to the division of the country.

$019562615 X, 456$ pages, OUP India

\section{From Lineage to State}

Social Formations of the Mid-First Millennium BC in

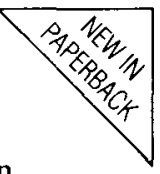
the Ganga Valley

\section{ROMILA THAPAR}

Examines Indian society in the crucial period of the mid-first millennium $\mathrm{BC}$ and in the seminal area of the Ganges Valley. 0195626753,198 pages, 1 map, paper covers, OUP India

These books are azailable now in bookshops. In case of difficulty, or for further information, please write to Fason Freeman, Oxford University Press, Walton Street, Oxford OX2 6DP. 